\title{
Budget Analysis, Employee Competence and Classification of Standard Account Charts in Realizing Reliability Financial Statements
}

\author{
Agus Prasetyo \& Rimi Gusliana Mais \\ Sekolah Tinggi Ilmu Ekonomi Indonesia Jakarta \\ Jakarta, Indonesia
}

\author{
Research Paper \\ Financial Management
}

\begin{abstract}
This research aims to analyze whether the Budget, Employee Competency and Standard Account Chart Classification (BAS) can realize the reliability of the Ministry of Maritime and Fisheries Financial Statements. This research uses descriptive research with a qualitative approach, research using interview techniques from informants. The population of this study is the Ministry of Maritime Affairs and Fisheries with the study sample determined based on work units with the authority of positions that exist within the Ministry. The results showed that dominantly employee competence can realize the reliability of the financial statements of the Ministry of Maritime Affairs and Fisheries because by placing employee competencies adjusted to the job will maximize work results. The budget and BAS can be structured properly when the competencies of employees can be met.
\end{abstract}

\section{Keywords:}

Budget, Employee Competency, Standard Account Chart and Reliability of Financial Statements

\section{Corresponding Author:}

Agus Prasetyo

Sekolah Tinggi Ilmu Ekonomi Indonesia Jakarta

Email: myboim28@gmail.com

(C) The Author(s) 2021

DOI: https://doi.org/10.36407/akurasi.v3i2.104
Received: 29 Nov 2020

Accepted: 25 Aug 2021

Online: 31 Aug 2021

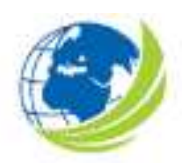

Akurasi: Jurnal Riset Akuntansi dan Keuangan, Vol 3, No.2, 2021, pp. $67-80$

eISSN 2685-2888

\section{(CC) (4)}

CC BY: This license allows reusers to distribute, remix, adapt, and build upon the material in any medium or format, so long as attribution is given to the creator. The license allows for commercial use. 


\section{INTRODUCTION}

Indonesia is a large country and of course as a large country Indonesia has a good governance system with no exception to the system of financial governance along with the reliability of the presentation of its financial statements. In short, the history of presenting financial statements may sound hard to believe, because for more than half a century of Indonesia's independence, the country's finances were managed according to rules made by the Dutch. In its journey, official regulations from the Government have been published, but basically the regulations used are those produced by the Dutch. Fresh air began to emerge when finally issued Decree of the Minister of Finance No. 476 of 1991 concerning Government Accounting Systems. However, due to the strength of the old regulations that have been planted in the minds of the country's financial managers, when the new regulations were finally published, the basic characteristics of Dutch regulations were difficult to remove.

According to Kholis and Khusnaini (2019: 6) in the management of state finances there is a budget which is a tool for the government to direct national economic development, ensure sustainability, and improve the quality of life of the people. In addition, according to Kholis and Khusnaini (2019: 7) one of the functions of the budget is as a means of control. As a means of control, the budget provides detailed plans for government revenues and expenditures so that expenditures made can be accountable to the public. Nainggolan (2012: 20) says that the budget has stages starting from Preparation, Ratification, Implementation, Reporting and Evaluation. However, the facts that exist regarding budgeting, implementation and accountability of the budget are not entirely in accordance with the function of the budget as a control tool. Based on the results of the Audit Board of the Republic of Indonesia (BPK-RI) examination in 2015 to 2018 on the Central Government Financial Report (LKPP), one of the findings related to the budget is as follows:

Table 1.

BPK-RI Findings on the Internal Control System Related to the Budget in the Central Government Financial Report, Year 2015 - 2018

\begin{tabular}{|c|c|c|}
\hline No & Years & Result Finding of BPK-RI \\
\hline 1 & 2015 & $\begin{array}{l}\text { Budgeting, Implementation, and Accountability of Capital Expenditures } \\
\text { in } 54 \text { KL of Rp5.62 Trillion and Goods Expenditures at } 63 \mathrm{~K} / \mathrm{L} \text { of Rp } 2.53 \\
\text { Trillion Not in Accordance with the Provisions }\end{array}$ \\
\hline 2 & 2016 & $\begin{array}{l}\text { Budgeting, Implementation, and Accountability of Capital Expenditures } \\
\text { at } 70 \mathrm{~K} / \mathrm{L} \text { of Rp9.80 Trillion and Goods Expenditures at } 73 \mathrm{~K} / \mathrm{L} \text { of } \\
\text { Rp1.11 Trillion and USD1,299.20, and Social Assistance Expenditures at } \\
5 \mathrm{~K} / \mathrm{L} \text { of Rp497.38 Billion Not in accordance with the provisions }\end{array}$ \\
\hline 3 & 2017 & $\begin{array}{l}\text { Budgeting, implementation, and accountability of expenditures at } 84 \mathrm{~K} / \\
\mathrm{L} \text { in the amount of Rp. } 25.25 \text { trillion and USD } 34,171.45 \text { not in accordance } \\
\text { with the provisions }\end{array}$ \\
\hline 4 & 2018 & $\begin{array}{l}\text { Planning, Implementation and Accountability of Government Policies } \\
\text { that Have Impacts on LRA Posts and / or Balance Sheets, as well as } \\
\text { Advantages and / or Shortfalls in Revenue for State-Owned Enterprises } \\
\text { Not Yet Regulated and Accounted }\end{array}$ \\
\hline
\end{tabular}

Source: LKPP Executive Summary 2015-2018

Tirau (2015) states that the adoption of traditional budgets has a negative impact on the amount of production costs, for that most companies leave the traditional costing system, and 
adopt a computer-based system on the concept of value and performance. Whereas Herianti (2019) stated that problems in managing the government budget in Indonesia for the 20152017 period were not carried out efficiently so as to cause budget deviations.

To understand the determination of BAS requires a financial management and accounting competency, according to Hazrita et al (2013) competence is a person's characteristics related to effective and / or superior performance in certain work situations. Competence is said to be an underlying characteristic because an individual's characteristic is a deep and inherent part of a person's personality that can be used to predict various specific work situations. Then said to be related between behavior and performance because competence causes or can predict behavior and performance. However, Competence is understood as knowledge, skills and basic values that are reflected in the habits of thinking, and acting. Competence can also be intended as the ability to carry out tasks obtained through education and/or training. According to Yuliansyah (2013) Government financial statements are made in accordance with Government Accounting Standards (SAP). In 2010 the Government of Indonesia amended Government Regulation number 24 of 2005 with Government Regulation number 71 of 2010 concerning Government Accounting Standards, according to article 4 paragraph 1 it states that the Government implements Accrual Based SAP with the existence of these Government Regulations, the Government has changed the accounting basis that previously used the basis Cash towards Accruals becomes the basis of Accruals. In the Conceptual Framework PP number 71 of 2010 related to the qualitative characteristics of financial statements mentioned that the qualitative characteristics of financial statements are normative measures that need to be realized in accounting information so that it can meet its objectives. The four characteristics that consist of relevant, reliable, comparable and understandable are the normative prerequisites needed so that government financial reports can meet the desired quality.

Djata (2018) concluded that the assistance budget had a significant effect and contributed to the welfare conditions of the fishing community. Winaya and Yudharta (2018) concluded that in terms of the analysis of the structure of the Village Expenditure Budget (APBDes) in several underdeveloped Category Villages in Kintamani District, Bangli Regency did not reflect performance-based APBDes as outlined in activities with expected outputs and outcomes including efficiency in achieving results and outputs that are prepared with a performance approach prioritizes outcomes and outputs by not excluding budgetary principles namely transparency, budget accountability, efficiency, budget effectiveness, budget discipline and budget fairness in accordance with one of the principles namely value for money especially in indicators economical that is not able to use all the budget obtained for activities to the community. Lamonisi (2016) provides the conclusion that with the issuance of government regulation number 71 of 2010 concerning accrual-based government accounting standards, the significance of the role of government in the public sector to realize transparent and accountable government is increasingly apparent. The government regulation becomes the legal basis for the government in preparing financial reports for both the central and regional governments. This indicates that the local government is no exception Tomohon City Government has an obligation to be able to immediately implement government regulation number 71 of 2010 regarding accrual-based government accounting standards. Kosegeran et al (2015) conclude that the results of the study indicate that the capacity of human resources affects the reliability of financial statements in the SKPD of the Government of Southeast Minahasa Regency.

Tirau (2015) concluded that most companies have abandoned traditional costing systems, and adopted computer-based systems on the concepts of value and performance. In the current economy, the only way to increase economic efficiency is to use budget costs efficiently. To survive in competition the company must find many ways to reduce costs and build the appropriate resources consumed. Makulova et al (2015) concluded that competency approaches in education are being developed in various countries, in various ways. There are many problems that require special research methodologies and methods. All of that is caused 
by differences in characteristics and education in each country. In shaping education in the context of a competency-based approach, we must ensure integration of fundamentality and the practical orientation of research. The competency-based educational research methodology is based on a behavioral and functional approach. In competency studies we must take into account the competencies of graduates, to predict potential competencies as a prerequisite for a successful career. From some of these studies the researchers suspect that the budget, employee competency and BAS classification have a role in realizing the reliability of financial statements.

The objectives of this research are: (1) to find out the reliability of financial statements on budget aspects in the Ministry of Maritime Affairs and Fisheries; (2) to find out the reliability of financial statements on aspects of employee competence at the Ministry of Maritime Affairs and Fisheries; and (3) to find out the reliability of financial statements on aspects of applying standard account charts at the Ministry of Maritime Affairs and Fisheries.

\section{LITERATURE REVIEW}

\section{The budget}

Government Regulation Number 90 Year 2010 concerning the Compilation of Work Plans and Ministries / Institutions Budgets Chapter I, Article 1 paragraph 17 states that the State Revenue and Expenditure Budget, hereinafter abbreviated as APBN, is the annual government financial plan approved by the DPR. According to Kholis and Khusnaini, (2019:3) Budget is one of the main instruments in implementing a predetermined policy. Besides the budget, other instruments for policy include human resources (HR), equipment, policy implementation methodology and others. But instruments outside the budget will be able to run if there is budget support. Kholis and Khusnaini (2019: 3). While Nasution (2019: 6) states that the budget is a tool to provide direction for the activities or activities to be carried out so that the activities carried out will be directed to the desired goals. In its application, the budget has a cycle, the budget cycle consists of the planning stage, the ratification stage, the implementation phase and the reporting or accountability stage. Alqadrie (2019: 116). In its implementation the budget performance evaluation is carried out to carry out measurements, assessments, and analysis of the Budget Performance of the current budget year and the previous budget year to prepare recommendations in order to improve the Budget Performance. Alqadrie (2019: 116).

\section{Employee Competency}

The term competency according to Webster's Dictionary (1596). This term is taken from the Latin word competere which means to be suitable. Then this changes substantially with the inclusion of various issues and discussion of the concept of competence from various literatures. Pianda (2018: 30) says that competency is a characteristic that underlies a person with regard to the effectiveness of an individual's performance in his work or basic characteristics that have a casual or causal relationship. Competence is an adequate skill to carry out a task or as possessing the required skills and abilities. Suparno (2012: 27).

Whereas Law No.13 of 2013 concerning Manpower states that competency is the work ability of every individual which includes aspects of knowledge, skills and work attitudes that are in accordance with established standards. According to Wibowo (2007: 110) states that competence is an ability to carry out or do a job or task based on skills and knowledge and is supported by the work attitude required by the job.

Makulova et al (2015) states that competence is a combination of knowledge, skills, abilities formed in the process of learning of a particular discipline, as well as the ability to perform any activity on the basis of the acquired knowledge, skills, and abilitie. Whereas Manzanera and Marin (2018) states that Professional competency is defined as the ability to apply knowledge, accomplishments and expertise to the professional field. However, in social work there is a significant contradiction between its definition and skills, and the existing competitiveness in the labor market. 


\section{Standard Account Chart Classification}

Minister of Finance Regulation No. 214 / PMK.05 / 2013 concerning Standard Account Chart in the Introduction Attachment states that a Standard Account Chart is a Standard Account Chart is a codefication list and classification related to financial transactions that are compiled and used systematically as a guide in planning, budgeting, budget execution, and government financial reporting. Chart of Standard Accounts (BAS) as a guide in preparing budget planning, budget execution, accountability and government financial reporting. Budgets in DIPA are classified in Standard Account Charts that are detailed to the organization, function, subfunction, program, activity and type of expenditure. Thus, the principle of specialty is actually used, ie the budget is specifically provided to finance certain activities and cannot be shifted without the revised DIPA mechanism in accordance with the provisions.

Tambunan (2016: 16), said that what is meant by the Standard Account Chart, hereinafter referred to as BAS, is a codefication list and classification related to financial transactions compiled systematically as a guideline for budget execution and government financial reporting. According to Okungbowa (2015: 27) A chart of accounts is a fundamental financial tool in SAP ERP. It Contains the list of general ledger (G / L) accounts used by a company code or several company codes for posting daily financial activities and for reporting financial performance to the financial statement and balance sheet.

\section{Reliability of Financial Statements}

Reliability is recording transactions in the accounting system that can be verified with objective evidence, such as payment receipts and bank statements. To be useful for its users, the information conveyed in the Financial Statements must have a quality of reliability that is free from misleading notions, material errors and presented honestly. An information that is maintained its reliability will help in making the right decision Nopriansyah (2019: 206). Government Regulation (PP) No 71 of 2010 Government Accounting Standards Statement (PSAP) Number 01. Stating that Reliability is a term that explains reasonable information, free from errors and irregularities and presents facts accurately. Reliability is a principle that must be applied, for example in purchasing goods, consumers must have a purchase receipt for the goods. Because receipts are evidence for consumers if the goods purchased are damaged or noted, so consumers can claim the goods Nopriansyah (2019: 206).

\section{METHODS}

\section{Research Strategies}

The method used in this research is a qualitative method with a descriptive approach. In this study the authors only describe social phenomena and phenomena that occur during the study. The reason the authors use descriptive research methods, because in this study the data collected in the form of words from the results of the interview and not the numbers. According to Anggito and Setiawan (2018: 8) Qualitative Research is the collection of data in a natural setting with the intention of interpreting phenomena that occur where the researcher is a key instrument, sampling data sources is done purposively and snowbally, collecting techniques with triangulation (combined), data analysis is inductive / qualitative, and qualitative research results emphasize more meaning than generalization. Qualitative research does not use statistics, but through data collection, analysis, and then interpreted.

\section{Sample and Data Collecting Methods}


Population is the totality of all possible values rather than the specific characteristics of the number of objects to be studied. Muri (2017: 147). According to Muri (2017: 148). Population can be classified into two types, namely: (a) the population is limited (definite), that is the object of research that can be calculated such as the area of rice fields, the number of livestock, the number of students and the number of students. (b) indefinite population, which is an object of research that has an unlimited number, or is difficult to count, such as ink, water, sand on the beach and rice paddies. Research Population determined by researchers is based on a limited population, namely the Ministry of Maritime Affairs and Fisheries.

The research sample that the researchers determined was the Work Unit of the Financial Bureau, the Secretariat of the Directorate General of Capture Fisheries, the Secretariat of the Directorate General of PDSPKP, and the Inspectorate General. Some data collection techniques according to Muri, (2017: 372) are Interviews, Observation and Documents. The interview technique has the following advantages:

1. Since the interviewer directly met the respondent, the response rate is also higher than the use of the questionnaire. If the source of information is not in place, it can be repeated at a later time.

2. The research sample is more in accordance with the plan because all sources of information will be found, if the researcher can wait when the information source is willing and ready to provide information

3. Can collect supplementary information that will be used to strengthen the evidence or analysis in preparing the research report.

4. Visualization of information can be presented and the interviewer can respond and ask for more detailed information and focus on the focus of the problem

Based on these considerations, in this study, researchers used interview techniques as data collection techniques. Planned-structured interviews will be conducted with the following informants:

Table 2.

Characteristics Informants

\begin{tabular}{|c|l|}
\hline Informant & \multicolumn{1}{|c|}{ Position } \\
\hline Informant 1 & Head of the Financial Bureau \\
\hline Informant 2 & Inspector I of the Inspectorate General \\
\hline Informant 3 & Head of Management Department of BMN Ministry \\
\hline Informant 4 & Head of Accounting Section of the Ministry \\
\hline Informant 5 & Head of Finance and General Section Directorate General of PDSPKP \\
\hline Informant 6 & Head of Finance and General Directorate General of Capture Fisheries \\
\hline Informant 7 & Intermediate Auditor General Inspectorate \\
\hline Informant 8 & Young Auditors Inspectorate General \\
\hline Informant 9 & Head of Financial Compliance and Risk Subdivision \\
\hline Informant 10 & Staff Implementing the Compilation of Financial Statements \\
\hline
\end{tabular}

\section{Data Analysis Method}


Moleong, (2000: 103) states that qualitative data analysis is the process of organizing and sorting data into patterns, categories and basic units of description so that themes can be found and work hypotheses can be formulated as suggested by the data. Qualitative research is expected to produce an in-depth description of speech, writing and behavior that can be observed from a particular individual or group in a particular setting context which is studied from a comprehensive and holistic perspective.

\section{RESULTS AND DISCUSSION}

\section{History and Profile of the Ministry of Maritime Affairs and Fisheries}

President Abdurrahman Wahid with Presidential Decree No.355 / M of 1999 dated October 26, 1999 in the Cabinet Period 1999-2004 appointed Ir. Sarwono Kusumaatmaja as Minister of Sea Exploration. Furthermore, the appointment was followed by the formation of the Department of Marine Exploration (DEL) along with details of its tasks and functions through Presidential Decree No. 136 of 1999 dated November 10, 1999 concerning the Position, Duties, Functions, Organizational Structure, and Work Procedures of the Department. It turned out that the use of the DEL nomenclature did not last long because based on the proposals from the DPR and various parties, there has been a change in the designation from the Minister of Sea Exploration to the Minister of Sea Exploration and Fisheries based on Presidential Decree Number 145 of 1999 dated 1 December 1999. This change was followed up by the replacement of the DEL nomenclature to the Department Sea and Fisheries Exploration (DELP) through Presidential Decree Number 147 of 1999 dated 1 December 1999.

In further developments, there has been an overhaul of the composition of the cabinet after the 2000 MPR Annual Session, and there was a change in the nomenclature of the DELP to the Ministry of Maritime Affairs and Fisheries (DKP) in accordance with Presidential Decree Number 165 of 2000 dated November 23, 2000 concerning Position, Duties, Functions, Authorities, Structure Department Organization and Work Procedure. Then it changed to the Ministry of Maritime Affairs and Fisheries in accordance with Presidential Regulation No. 47 of 2009 concerning the Formation and Organization of State Ministries, the Nomenclature of the Ministry of Maritime Affairs and Fisheries became the Ministry of Maritime Affairs and Fisheries.

The establishment of the Ministry of Maritime Affairs and Fisheries is basically a challenge, as well as an opportunity for the development of the Indonesian marine and fisheries sector. That is, how does this KKP place the marine and fisheries sector as one of the mainstay sectors that are able to deliver the Indonesian Nation out of a prolonged economic crisis. There are at least a number of underlying reasons. First, Indonesia as an archipelagic country with 17,508 islands and 81,000 km of coastline is not only the largest archipelago in the world but also stores a large wealth of marine natural resources and has not been used optimally. Secondly, for decades, the country's development orientation has been more directed towards land, resulting in land resources being drained. Therefore it is natural that marine and fisheries resources grow in the future. Third, associated with the rate of population growth and increasing human awareness of the importance of fisheries and marine products for human health and intelligence, it is believed that it can still improve fisheries and marine products in the future. Fourth, dynamic coastal and marine areas not only have resource potential, but also have the potential for the development of various extractive development activities such as industry, settlement, conservation and so on.

The organizational structure of the Ministry of Maritime Affairs and Fisheries is contained in the Regulation of the Minister of Maritime Affairs and Fisheries Number 7 / 
PERMEN-KP / 2018 concerning Amendment to the Regulation of the Minister of Maritime Affairs and Fisheries Number 6 / Permen-Kp / 2017 Regarding Organization and Work Procedure of the Ministry of Maritime Affairs and Fisheries.

\section{The budget}

The results of interviews with several informants about the understanding of the budget ranging from the meaning of the budget to the relationship between the budget and the financial statements are obtained as follows:

According to informant 1 related to the budget

"The budget is the planned funding needs to be used to finance all routine operational needs of the Ministry as well as priority activities to achieve short-term or annual, medium-term and long-term goals." ... "budget execution is not in accordance with the medium-term program that has been agreed by The DPR will certainly make budget accountability unfavorable, finally what?... I can be sure there will be a lot of accounting adjustments there and if that happens surely BPK auditors will suspect what is wrong? Why are there so many adjustments? ... this will definitely affect the reliability when the financial statements will be published".

The statement of informant 1 was reinforced by informant 2 regarding the budget

"The budget is administered by the ministry or in the Ministry of Maritime Affairs and Fisheries related to the government, of course related to the State Budget, contained in PP 90 of 2010. The State Budget is a financial plan prepared annually by the state government which is certainly approved by members of Parliament."... "in the budget that needs attention not only at the stage of implementation and accountability but should be emphasized more at the planning stage, so that later the presentation of financial statements can be reliable ..."

While the decisive statement by informant 5 regarding the budget is

"... we must present the financial statements according to the facts that are then applied. Then the financial statements can be assessed for reliability. It means that if there is a change in the budget it is also necessary to explain the cause so that the compiler of the financial statements does not misrepresent the facts to be presented "

From all the information above it can be explained that the budget in principle is a financial plan prepared both with short-term, medium-term and long-term goals to be used to finance the operational needs of the government determined through an agreement mechanism by the House of Representatives of the Republic of Indonesia (DPR RI). Presentation of the planning stage to the accountability of the budget in the financial statements must be in accordance with the facts available so that the financial statements can be assessed reliably.

\section{Employee Competency}


The results of interviews with several informants about understanding employee competencies to the relationship of employee competencies with the reliability of financial statements are described as follows:

Information obtained from informant 1 regarding employee competencies is

"Competence is the ability to complete tasks given by the leadership, competence can be influenced by the level of education." ... "not all of it is appropriate, there are still employees who are competently incompatible, the KKP is a Ministry that was originally formed from the Ministry of Agriculture where at at that time many of the employees in charge of managing finance had disciplines not from graduates of economics or bookkeeping. "..." employee competence if we use the term "right man on the right place and the right time" would certainly affect the reliability or quality of financial statements, as for example, if an accounting graduate employee who is assigned as a financial statement compiler is almost certain to be better than an employee who is not an accounting graduate, graduates of government accounting will almost certainly be more leverage in presenting government financial reports than a graduate employee and from private sector accounting "

This information was strengthened by informant 4 stating that

"The condition of employee competence in KKP is not yet fully appropriate, both from the educational background and skills," .... whereas the purpose of employee competency is the ability of employees to complete work in accordance with their skills and education. "... for example with the normal conditions of an employee with graduates from economics or accounting though not long ago working on understanding about how to plan budgets, carry out budgets and be accounted for will almost certainly be different from employees who are not from basic economic or accounting education "Employee competence becomes important and dominant in the presentation of reliable financial reports, because the facts of each event in a transaction can only be presented by competent employees."

Other information according to informant 10 also strengthens by stating that "Competence can affect the reliability of financial statements because if employees with competencies still have different scientific disciplines, misstatements may occur in the preparation of financial statements, because these employees do not know for certain the substance that occurs or the facts that have occurred".

From the various information available about competence, it can be explained that employee competency is the ability of employees to complete tasks. Competence is an ability that is influenced by an educational background. Competence becomes the dominant thing in realizing the reliability of financial statements, because with the appropriate competence, the presentation of financial statements honestly in accordance with the facts, can be tested and neutral which is a reliable criterion can be realized.

\section{Standard Account Chart (BAS)}

Some opinions from informants related to understanding BAS to the association of BAS with the reliability of financial statements are described as follows:

The opinions obtained from Infoman 1 say that 
"BAS is account codification, so BAS is a collection of account coding, which is the same that is used not only by the KKP but all KLs in uniforming the budgeting process until financial reporting." will be used in the budget, and it is better if the BAS determination also involves the staff compiling the financial statements and APIP so that the use of BAS can be more targeted ". ... "BAS can be a factor that affects the reliability of financial statements depending on the employees who apply the BAS provisions themselves. If there is a revision in the use of BAS but it is not disclosed honestly so that it cannot be tested by verifiers then the financial statements can be unreliable. "

Informant 1's opinion was confirmed by informant 6 who stated that

"BAS is indeed one of the control tools and it is better that those who determine the use of BAS are economists so that when budget planning is well structured." ... simple events for purchasing uniforms usually officers only know that the BAS used is 52 shopping for goods, but if you want to pay closer attention to the use of an account in the appropriate $B A S, 521211$, namely material expenditure, the error in determining this BAS can be fatal if internal control is not carried out, for this reason, when compiling or revising, approval from the Finance Bureau, Planning Bureau and review by APIP. "... more woe if there is a change in BAS not presented in the $L K$, it could be a misstatement that does not appear to have a negative budget ceiling ... it could be that $L K$ is judged to be not reliable by the examiner".

Strengthening the opinions of informants 1 and 6, informant 7 states that

"... BAS is a codification that has been regulated in a provision by the Ministry of Finance."

... BAS functions as a control tool from the budget planning stage to financial management accountability. "..." Conditions in the CTF have not all been orderly in implementing BAS in accordance with existing provisions. This happens because the understanding among employees is not the same, other than that because the time for determining BAS when budget planning is too narrow so that revisions to the BAS implementation often occur. "..." Revisions to the use of BAS could be a factor affecting the reliability of financial statements if after testing at the time of the review by APIP, the officer cannot explain or not be presented according to the facts when presented in the notes to the financial statements. "

From several informants' opinions regarding BAS, the researcher explained that BAS was codified in a provision by the Ministry of Finance. BAS is a means of controlling the planning process to financial accountability. The application of BAS must be carried out by competent employees so that there is no revision of BAS usage. If there is a revision of the use of BAS it is necessary to explain in the notes to the financial statements so as not to cause misstatements that can affect the reliability of the financial statements.

\section{Reliability of Financial Statements}

Regarding the Reliability of Financial Statements, several informants stated their opinions as follows: Informant 2's opinion regarding the reliability of financial statements is "... financial statements can be said to be reliable if the financial statements can be tested and disclosed in accordance with the facts that occur.

" ... "Many factors can affect the reliability of financial statements, could be from the budget cycle, could be due to employee competence, could be due to an accounting system 
that currently used, or it could be because there are interests from the leadership of the entity. But it all depends on the character of the existing employees, if the employee understands the substance of each job that is given professionally, the reliability of the financial statements can certainly be realized in accordance with the ultimate goal of the CTF. "

Whereas informant 4 strengthened by stating that

"... related to the reliability of financial statements should be returned again in PP 71 of 2010 where the word reliable is one of the qualitative characteristics of financial statements in which information must be free from misleading understandings, testable and not in favor of any interest." ... "Disclosure of information depends of the competence of employees in charge of preparing financial statements. "..." Errors in the implementation of the budget and the determination of BAS so that revisions can be made can make financial reports unreliable if disclosure of information does not match the facts so that it is misleading, "..." on the contrary the financial statements can be reliable if the disclosure of information is in accordance with the facts in accordance with the limits of the reasonableness of the information to be disclosed. "..." All can be realized depending on the competence of employees who will disclose. "

The opinions of informant 2 and informant 4 are confirmed by informant 8 by stating that "... as an auditor, my opinion, the reliability of financial statements can be realized if the financial statements can be tested in accordance with the facts that occur whether it is in accordance with the provisions in force.

"..."The reliability of financial statements is closely related to the competence and character of employees who prepare the financial statements themselves, because with competent employees the presentation of financial statements will be tested for compliance with applicable regulations and facts. "..." My experience in LK audits at KKP is that almost all review objects whose officers are graduates of economics are well prepared, meaning that they can be tested for accuracy, according and the documents there."

From the various opinions of the informants it can be explained that related to the reliability of financial statements is qualitative information that should be in accordance with the facts that exist so that it is free from misleading notions other than that the information must be able to be verified. The reliability of financial statements can be realized if the employees who compile financial statements have the competence in disclosing information.

\section{CONCLUSION}

The budget can realize reliable financial reports if planned, implemented and accounted for properly in accordance with the provisions. Competence becomes the dominant thing to create a reliable financial report, with employees who are competent in planning, implementing and compiling budgetary accountability in the financial statements will provide maximum results in accordance with the actual facts in the presentation of information in the financial statements. Applying the right BAS can realize reliable financial reports because with this accuracy it will reduce adjustments in the accounting system applied when preparing financial statements 
The budget can be considered, because it can affect the reliability of financial statements. Placement of employees in the KKP environment evaluates the results of recruiting prospective employees and assesses employees who specifically carry out their duties as budget planners, budget executors, and budget accountability so that their competencies are adjusted. Implementation of BAS is carried out thoroughly control so that errors do not occur that can affect the reliability of financial statements. There needs to be synergy between all parties involved in order to realize the reliability of financial statements

\section{REFERENCES}

Badan Pemeriksa Keuangan - Republik Indonesia. (2016). Ringkasan Eksekutif Laporan Hasil Pemeriksaan BPK-RI atas Laporan Keuangan Pemerintah Pusat Tahun 2015. Nomor 56/LHP/XV/05/2016 : Jakarta

Badan Pemeriksa Keuangan - Republik Indonesia. (2017). Ringkasan Eksekutif Laporan Hasil Pemeriksaan BPK-RI atas Laporan Keuangan Pemerintah Pusat Tahun 2016. Nomor 60/LHP/XV/05/2017 : Jakarta

Badan Pemeriksa Keuangan - Republik Indonesia. (2018). Ringkasan Eksekutif Laporan Hasil Pemeriksaan BPK-RI atas Laporan Keuangan Pemerintah Pusat Tahun 2017. Nomor 64/LHP/XV/05/2018 : Jakarta

Badan Pemeriksa Keuangan - Republik Indonesia. (2019). Ringkasan Eksekutif Laporan Hasil Pemeriksaan BPK-RI atas Laporan Keuangan Pemerintah Pusat Tahun 2018. Nomor 71/LHP/XV/05/2019 : Jakarta

Djata, B. T. (2018). Peran pendamping serta dampak anggaran di bidang kelautan dan perikanan terhadap kondisi kesejahteraan masyarakat nelayan di Kabupaten Ende. Jurnal Perilaku dan Strategi Bisnis, 6(1), 78-102.

Herianti, E. (2019). Turbulensi Anggaran dan Deviasi Anggaran: Dari Pemerintah Memiliki Kemampuan untuk Menguranginya?. Jurnal Tata Kelola \& Akuntabilitas Keuangan Negara, 5(1)

Hindriani, N., Hanafi, I., \& Domai, T. (2012). Sistem Pengendalian Intern Pemerintah (SPIP) Dalam Perencanaan dan Pelaksanaan Anggaran di Daerah (Studi Pada Dinas Kesehatan Kabupaten Madiun). Wacana Journal of Social and Humanity Studies, 15(3), 1-9.

Kariangga, H. (2017). Carut Marut Pengelolaan Keuangan Daerah di Era Otonomi Daerah. Perspektif Hukum dan Politik. Depok: Kencana

Kountur. R. (2004). Metode Penelitian Untuk Penulisan Tesis dan Tesis. Edisi Revisi. Jakarta. Penerbit PPM Manajemen

Keputusan Direktur Jenderal Perbendaharaan Nomor KEP-211/PB/2018 tentang Kodefikasi Segmen Akun Pada Bagan Akun Standar

Keputusan Menteri Kelautan dan Perikanan Nomor 110/KEPMEN-KP/SJ/2019 tentang Tata Cara Usulan Revisi Anggaran Di Lingkungan Kementerian Kelautan Dan Perikanan

Makulova, A. T., Alimzhanova, G. M., Bekturganova, Z. M., Umirzakova, Z. A., Makulova, L. T., \& Karymbayeva, K. M. (2015). Theory and practice of competency-based approach in education. International Education Studies, 8(8), 183-192.

Muri, Y. (2017). Metode Penelitian Kuantitatif. Kualitatif \& Penelitian Gabungan. Kencana: Jakarta

Peraturan Pemerintah Nomor 8 Tahun 2006 tentang Pelaporan Keuangan dan Kinerja Instansi Pemerintah

Peraturan Pemerintah Nomor 71 Tahun 2010 tentang Standar Akuntansi Pemerintah

Peraturan Pemerintah Nomor 90 Tahun 2010 tentang Penyusunan Rencana Kerja dan Anggaran Kementerian Negara/Lembaga

Peraturan Menteri Keuangan Nomor 214/PMK.02/2017 tentang Pengukuran dan Evaluasi Kinerja Anggaran atas Pelaksanaan Rencana Kerja dan Anggaran Kementerian/Lembaga. 
Peraturan Menteri Keuangan Nomor 11/PMK.02/2018 tentang Tata Cara Revisi Anggaran Tahun Anggaran 2018.

Peraturan Menteri Keuangan Nomor 214/PMK.02/2017 tentang Pengukuran dan Evaluasi Kinerja Anggaran Atas Pelaksanaan Rencana Kerja dan Anggaran Kementerian Negara/ Lembaga.

Peraturan Menteri Keuangan Nomor 177/PMK.05/2015 tentang Pedoman Penyusunan dan Penyampaian Laporan Keuangan Kementerian Negara /Lembaga.

Peraturan Menteri Keuangan Nomor 222/PMK.05/2016 tentang Perubahan Peraturan Menteri Keuangan Nomor 177/PMK.05/2015 tentang Pedoman Penyusunan dan Penyampaian Laporan Keuangan Kementerian Negara /Lembaga.

Peraturan Menteri Keuangan Nomor 225/PMK.05/2016 tentang Penerapan Standar Akuntansi Pemerintahan Berbasis Akrual Pada Pemerintah Pusat

Peraturan Menteri Kelautan dan Perikanan Nomor 39/PERMEN-KP/2018 tentang Pedoman Umum Penyusunan Rencana Kerja dan Anggaran Kementerian Kelautan.

Peraturan Badan Pemeriksa Keuangan - Republik Indonesia Nomor 1 Tahun 2017 tentang Standar Pemeriksaan Keuangan.

Tirau, A. I. (2015). Chart Of Accounts, Organizational Tool Into The Corporates. AnnalsEconomy Series, 6, 472-475.

Undang-Undang Nomor 17 Tahun 2003 tentang Keuangan Negara

Undang-Undang Nomor 1 Tahun 2004 tentang Perbendaharaan Negara

Undang-Undang Nomor 15 Tahun 2004 tentang Pemeriksaan Pengelolaan dan Tanggung Jawab Keuangan Negara.

Winaya, I. K., \& Yudharta, I. D. (2018). Desa Membangun: Analisis Perencanaan dan Penyusunan Anggaran Pendapatan dan Belanja Desa (APBDes) Tahun 2017 (Studi Kasus di Desa Kategori Tertinggal Pada Kecamatan Kintamani Kabupaten Bangli). Fakultas Ilmu Sosial dan Ilmu Politik Universitas Udayana.

Yamashita, T., Cummins, P. A., Arbogast, A., \& Millar, R. J. (2018). Adult competencies and employment outcomes among older workers in the United States: An analysis of the program for the international assessment of adult competencies. Adult Education Quarterly, 68(3), 235-250.

Zamzami, F., \& Faiz, I. A. (2018). Audit Internal: Konsep Dan Praktik. UGM PRESS. 


\section{DECLARATIONS}

\section{Funding}

The authors received no financial support for the research and publication of this article.

\section{Conflicts of interest/ Competing interests:}

The authors have no conflicts of interest to declare that are relevant to the content of this article.

\section{Data, Materials and/or Code Availability:}

Data sharing is not applicable to this article as no new data were created or analyzed in this study.

\section{How to cite this Article}

Prasetyo, A., \& Mais, R. (2021). Budget Analysis, Employee Competence and Classification of Standard Account Charts in Realizing Reliability Financial Statements. AKURASI: Jurnal Riset Akuntansi Dan Keuangan, 3(2), 67 - 80 